\title{
MONIKA OKULICZ
}

Uniwersytet Przyrodniczy w Poznaniu

Katedra Fizjologii, Biochemii i Biostruktury Zwierzat

Wołyńska 35, 60-637 Poznań

E-mail: mokulicz@au.poznan.pl

\section{HILARY KOPROWSKI (5.12.1916-11.04.2013) - POLSKI LEKARZ, PIONIER WIRUSOLOGII I IMMUNOLOGII, PIANISTA KLASYCZNY, WIZJONER, ERUDYTA}

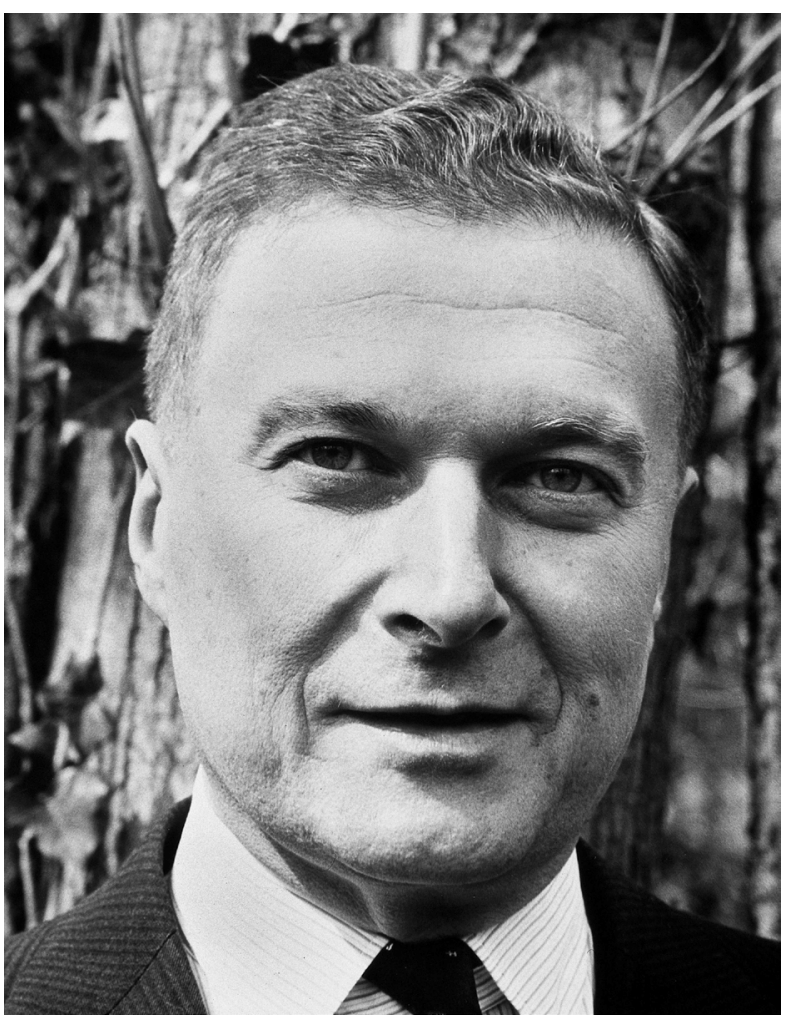

Hilary Koprowski (1916-2013)

Wybitny naukowiec, pionier wirusologii i immunologii, twórca pierwszej w świecie doustnej szczepionki przeciw wirusowi poliomyelitis („polio”) wywołującemu chorobę Heinego-Medina, a także ulepszonej szczepionki przeciw wściekliźnie i różyczce, inicjator badań nad przeciwciałami monoklonalnymi w diagnostyce nowotworów i immunoterapii. Opublikował ponad 900 prac naukowych. Dyrektor Instytutu Wistara (1957-1991) oraz profesor Instytutu Biotechnologii i Zaawansowanej Medycyny Molekularnej, dyrektor
Centrum Neurowirusologii i Laboratoriów Fundacji Biotechnologii w Thomas Jefferson University (1992-2013) w Filadelfii. Erudyta i humanista, gigant intelektu, poliglota, wielki miłośnik muzyki, sztuki i poezji. Autor opowiadań, wierszy, sztuk teatralnych, utworów muzycznych.

Doktor honoris causa kilku światowej sławy uniwersytetów. Wieloletni członek Amerykańskiej Narodowej Akademii Nauk i Polskiej Akademii Nauk. Uhonorowany licznymi godnościami akademickimi oraz odznaczeniami narodowymi wielu państw (USA, Polska, Francja, Belgia, Finlandia, Szwecja, Niemcy). W 2012 r. dzieci polskie mianowały prof. H. Koprowskiego Kawalerem Orderu Uśmiechu. W roku stulecia odzyskania niepodległości przez Polskę, 11. listopada 2018, pośmiertnie uhonorowany Orderem Orła Białego dla niezwykłych Polaków. Patron m. in. Gdańskiego Parku Naukowo-Technologicznego.

\section{Hilary Koprowski (1916-2013)}

Outstanding scientist, pioneer of virology and immunology, creator of the world's first oral vaccine against the poliomyelitis virus ("polio") that causes Heine-Medina disease, as well as an improved vaccine against rabies and rubella, initiator of research on monoclonal antibodies in cancer diagnostics and immunotherapy. He has published over 900 scientific papers. Director of the Wistar Institute (1957-1991) and professor at the Institute of Biotechnology and Advanced Molecular Medicine, director of the Center for Neurovirology and Laboratories of the Biotechnology Foundation at Thomas Jefferson University (1992-2013) in Philadelphia. Erudyta and humanist, giants of intellect, 
polyglot, great lover of music, art and poetry. Author of short stories, poems, plays and musical works.

Honorary doctorate of several world-famous universities. A long-time member of the American National Academy of Sciences and the Polish Academy of Sciences. Honored with numerous academic honors and national decorations of many countries

Profesor Hilary Koprowski urodził się 5. grudnia 1916 r. w Warszawie, zmarł 11. kwietnia 2013 r. w Wynnewood pod Filadelfią; Pensylwania, USA. Jego Matka, Zofia Siemionowna (1883-1967), z domu Berland, była jedna $z$ pierwszych kobiet stomatologów w przedrewolucyjnej Rosji. Ojciec, Paweł Koprowski (1882-1957), był zamożnym właścicielem doskonale prosperujacej firmy produkujacej i handlującej angielskimi tekstyliami. Od dziecka Rodzice wpajali swojemu jedyne$\mathrm{mu}$ dziecku zamiłowanie do książek i muzyki. Jak sam Koprowski podkreślał w licznych wywiadach, gruntowne wykształcenie klasyczne, które mu wiele razy pomagało $\mathrm{w}$ przyszłości, zawdzięczał 8-letniej edukacji w Gimnazjum im. Mikołaja Reja Zboru Ewangelicko-Augsburskiego w Warszawie (19261934). Stało się to dzięki wybitnej kadrze nauczycieli, ale i wyjątkowym kolegom. $\mathrm{Na}$ etapie gimnazjum szczególnie fascynowała go historia i literatura. Należał do Kółka Literackiego i pozaszkolnego Kółka Poetów. Z gimnazjum wyniósł szacunek dla etosu dla pracy, wolności sumienia i tolerancji. W trzeciej klasie gimnazjalnej rozpoczął równolegle naukę w Warszawskim Konserwatorium, gdzie uczył się gry na fortepianie. Po wybuchu wojny edukacje muzyczna kontynuował w sławnej Akademii Muzycznej Św. Cecylii w Rzymie (studiował u wybitnego pianisty Carla Zecchiego), a następnie pobierał prywatne lekcje komponowania w USA.

W latach 1934-1939 studiowal medycynę na Wydziale Lekarskim Uniwersytetu Medycznego im. Józefa Piłsudskiego w Warszawie. Razem $\mathrm{z}$ żona byli $\mathrm{w}$ ostatniej grupie studenckiej, która ukończyła wydział lekarski przed druga wojna światowa. Jako hospitant na trzecim roku studiów odbył praktykę w Zakładzie Patologii Ogólnej i Doświadczalnej pod kierownictwem prof. Franciszka Venuleta (1878-1967), pioniera badań nad szkodliwościa palenia tytoniu. W ramach praktyki Koprowski odbył też staż w University College w Dublinie, który zaowocował pierwsza w Jego ogromnym dorobku naukowym publikacja dotyczaca amoniaku w ustroju (KOPROWSKI i UNIŃSKI 1939).

Najbliższa towarzyszką i niezwykle oddanym partnerem we wszystkich przedsięwzięciach Hilarego Koprowskiego była Jego żona
(USA, Poland, France, Belgium, Finland, Sweden, Germany). In 2012, Polish children appointed prof. H. Koprowski Knight of the Order of the Smile. In the year of the centenary of Poland regaining independence, on November 11, 2018, he was posthumously honored with the Order of the White Eagle for extraordinary Poles. Patron, among others Gdańsk Science and Technology Park.

Irena Grasberg (1917-2012). Wspólnie przeżyli 74 lata. Jako pierwsza kobieta uzyskała tytuł profesora na Akademii Medycznej im. Hahnemanna w Filadelfii, gdzie kierowała Zakładem Patologii. Na Uniwersytecie Temple była dyrektorem działu cytologii. Była też założycielką Amerykańskiego Towarzystwa Cytopatologów i konsultantka WHO w dziedzinie cytodiagnostyki.

Hilary Koprowski w trakcie wojny wyemigrował najpierw do Włoch, potem do Brazylii, a w 1944 r. osiadł na stałe w USA. We Włoszech pracował jako lekarz w polskim konsulacie w Rzymie. Jako oficer medyczny badał rekrutów do polskich oddziałów, których odsyłano do Coetquidan we Francji. Po przystapieniu Włoch do wojny, Koprowski wyemigrował do Brazylii. W zdobyciu brazylijskiej wizy emigracyjnej pomogły Jego umiejętności muzyczne. Konsul generalny Brazylii, u której grał na koncertach, okazała się być wielbicielka muzyki klasycznej i zaoferowała pomoc. W Brazylii poczatkowo praktykował jako lekarz i dawał koncerty. Przypadkowe spotkanie $z$ Lutym Kossobudzkim, kolega z czasów gimnazjalnych, na plaży w Rio de Janeiro, zaważyło na dalszej imponujacej karierze naukowej Koprowskiego. Za radą Kossobudzkiego zgłosił się do laboratorium Fundacji Rockefellera w Rio de Janeiro, gdzie otrzymał posade asystenta. W Fundacji Rockefellera pracował nad szczepionką z żywych wirusów przeciwko żółtej febrze, wirusami neurotropowymi i mózgowymi pod okiem, jak sam mawiał, mistrza i jedynego nauczyciela wirusologii Edwina Lennette (1908-2000), o polskich korzeniach. We wspólnie opublikowanych 4 artykułach $z$ 1945 i 1946 r. pierwsi na świecie zwrócili uwage na istnienie antywirusowej substancji, nazwanej później interferonem.

W 1944 r., po czterech latach pobytu w Brazylii, wraz $z$ rodzina przypłyną do USA. Pierwszy miesiąc spędził w Instytucie Rockefellera w Nowym Jorku. Zaprzyjaźnił się z Noblista Maksem Theilerem (1899-1972), pionierem szczepionek $z$ żywego wirusa. Badania Theilera okazały sie najbardziej zachęcajacym wzorem dla bardzo zdolnego i utalentowanego młodego Koprowskiego. Następnie, w 1945 r. otrzymał posade naukowca w Lederle Laboratories, farmaceutycznej części 
koncernu American Cyanamid w Pearl River, New York, u równie genialnego wirusologa Heralda Coxa (1907-1986). Poczatkowo H. Koprowski pracował nad szczepionka przeciw encefalitowi japońskiemu (wirusowemu zapaleniu mózgu). Choroba, przenoszona przez komary, zagrażała amerykańskim żołnierzom stacjonującym na Pacyfiku. Praca nad szczepionka dla wojska zwolniła Koprowskiego $z$ poboru do armii amerykańskiej. Kolejne badania dotyczyły doustnej szczepionki przeciw poliomyelitis („polio”). Wirus polio wywołuje ostre nagminne porażenie dziecięce (łac. poliomyelitis anterior acuta), chorobę odkryta i opisana przez niemieckiego lekarza Jakoba Heinego (1800-1879) i szwedzkiego pediatrę Karla Oskara Medina (1847-1927). W latach 40. XX w. Stany Zjednoczone borykały się $z$ potężnym problemem polio; jedną $z$ ofiar był sam Prezydent Franklin Delano Roosvelt (1882-1945). W tym okresie choroba Heinego-Medina przybrała rozmiary pandemiczne (10000-60000 przypadków rocznie w USA i wiele więcej na całym świecie). W poszukiwaniu szczepionki na wirus polio w USA, oprócz Hilarego Koprowskiego, wzięło również udział dwóch głównych starszych konkurentów: Albert Sabin (1906-1993) z Uniwersytetu w Cincinnati oraz, młodszy od Sabina, Jonas Salk (1914-1995), naukowiec $z$ Uniwersytetu w Pittsburghu. Salk preferował szczepionkę $z$ martwych wirusów. Koprowski i Sabin pracowali nad szczepionka $z$ osłabionych żywych wirusów. Sabin i Koprowski podjęli się znacznie trudniejszego zadania niż Salk. Trudniej było osłabić wirus, niż go zabić. Co więcej, każdy szczep musiał być na tyle silny, by wywołać łagodne zakażenie i jednocześnie wystarczajacco słaby, by więcej nie szkodzić. Szczepionka z żywych wirusów miała praktyczne zalety. Podawana doustnie była naturalna droga dla wirusa polio. Pojedyncza dawka wystarczała do uodpornienia pacjentów na całe życie. Działała té̇ szybciej, powodując odporność w ciagu kilku dni. Co istotne, była prosta w użyciu i zapewniała również tzw. „bierne szczepienie społeczeństwa" poprzez odchody ludzkie.

Test prawdy, wraz ze współpracownikami, odbył Koprowski w styczniu 1948 r. wypijajacc „koktajl polio". Były to zmiksowane kawałki rdzenia kręgowego i tkanki mózgowej zainfekowanego wirusem polio szczura bawełnianego, odpornego na badany wirus. Inaktywowanie (atenuowanie) wirusa uzyskano ostatecznie poprzez jego wielokrotny pasaż w mózgach szczurów. Dwa lata później, 27 lutego 1950 r., przetestował swoja szczepionkę na 20 chłopcach w wiosce Letchworth Village, gdzie znajdowało się państwowe schronisko dla dzieci $z$ upośledzeniem umysłowym. To było pierwsze na świecie pomyślne prze- prowadzone szczepienie przeciwko polio, bezprecedensowe wydarzenie $w$ historii medycyny świata. W ciagu następnych kilku dni zaszczepiono $z$ jednakowym sukcesem ponad tysiac dzieci w Ameryce.

W marcu 1951 r. Koprowski przedstawił swoje wyniki w trakcie Konferencji Okragłego Stołu zorganizowanej przez Narodowa Organizację w Hershey, w stanie Pensylwania. Obecni tam byli również Albert Sabin i Jonas Salk. Został bardzo skrytykowany przez Sabina, choć jeszcze w tym samym roku, Sabin rozpoczał sam pracę nad szczepionka z żywych wirusów. Stało się to w dodatku, po jednostronnej wymianie szczepów wirusa $z$ Koprowskim. Jego koncepcja była analogiczna do pomysłu Koprowskiego, $z$ tym że przetestował trzy odrębne zakaźne szczepy osłabionego wirusa (bez użycia adjuwanta), a Koprowski poczatkowo badal tylko jeden szczep typu II, tzw. Lansing $z$ użyciem adjuwanta. W 1954 r. Sabin dokonał analogicznej próby testowej na 30 więźniach w miejscowości Chillicothe.

Paradoksem pozostaje fakt, że szczepionka Koprowskiego nigdy nie została dopuszczona do użycia w Stanach Zjednoczonych, pomimo odnotowanej skuteczności w Afryce i w Europie, kilka lat przed szczepionka Alberta Sabina. W sierpniu 1960 r. ówczesny minister zdrowia Stanów Zjednoczonych podał do publicznej wiadomości o wyborze szczepionki Sabina w USA. Jako argument ostatecznego wyboru doustnej szczepionki Sabina podano łatwość w stosowaniu, skuteczność i niższą cenę jej produkcji. Tym samym doustna szczepionka Sabina przeciw polio wyparła domięśniową szczepionkę Salka w USA i większości krajów świata. Doustne szczepionki Koprowskiego zostały zaś odrzucone w USA ze względu na wymóg bezpieczeństwa związanego $z$ domniemana większą zjadliwością. Jednak podłoże tej decyzji, zamiast medyczno-naukowego, było polityczne. W odróżnieniu od Koprowskiego, Sabin miał znaczace wsparcie $z$ Narodowej Fundacji do Walki $z$ Paraliżem Dziecięcym (ang. March of Dimes). Koprowskiego uważano za komercyjnego naukowca pracujacego dla profitów prywatnych firm. Dzięki niezłomnej osobowości, awantura o polio tylko wzmocniła Koprowskiego. Mógł ze spokojem realizować kolejne zadania badawcze wciąż jako pierwszy naukowiec, który miał odwagę zaszczepić ludziom żywego wirusa polio.

W Laboratorium Lederle przez ostatnie 9 lat pracował jako zastępca dyrektora Section of Viral and Rickettsial Research. W 1957 r. H. Koprowski postanowił opuścić Lederle. Przeją funkcję dyrektora upadającego Instytutu Anatomii i Biologii im. Wistara w Filadelfii, założonego przez Isaaka Wistara w 
1892 r. Instytutem kierował blisko 35 lat, do 1991 r. W tym czasie przekształcił Instytut Wistara $z$ upadajacej, muzealnej placówki, w instytut badawczy o światowej reputacji, jedno $z$ najważniejszych centrów badawczych na świecie. Przez dekady stworzył bardzo silną, uzdolniona grupę naukowców, która $z$ czasem zasilała kadry medyczne różnych państw. Filozofia instytutu oparta była na braku podziału na departamenty, wydziały, zakłady. Koprowski uważał, że każda centralizacja prowadzi do biurokracji, niepotrzebnej konkurencji, zakłócania współpracy zbędnymi „prestiżowymi” sporami. Administracja prowadzona była przez samych pracowników naukowych, tym samym ograniczajac biurokrację do niezbędnego minimum. W nowym instytucie kontynuował badania nad polio i wścieklizna. Wraz ze współpracownikiem, doktorem weterynarii Tadeuszem Wiktorem (1920-1986), opracował ulepszona szczepionkę przeciw wściekliźnie, powstała na bazie kultury tkanek (embriony kurze), a nie mózgów zwierzęcych, jak pasteurowska. Charakteryzowała się imponująca skutecznością: wywoływała wysoki poziom przeciwciał, umożliwiała skrócenie serii zastrzyków z 21 lub 14 do 3 lub 4 podawanych podskórnie lub domięśniowo, a nie jak dotą, pod skórę brzucha. W latach 70. XX w. zespól badawczy Koprowskiego opracował kolejna szczepionkę przeciw wściekliźnie, rekombinowana VR-G, podawaną w przynęcie, tym razem w celu uodpornienia zwierząt dziko żyjących (szopy, lisy). Dzięki niej udało się m.in. wyeliminować wściekliznę u lisów we Francji i w Belgii.

Równoległym przedmiotem badań w Instytucie Wistara był m.in. wirus pomoru świń, japońskiego zapalenia mózgu B, gorączki Kolorado, łącznie ponad 25 różnych wirusów. Obok wirusów, prowadzono eksperymenty nad stwardnieniem rozsianym, starzeniem się organizmu i wrażliwością guzów rakowych na wirusy. Bardzo istotnym osiagnięciem Instytutu Wistara było udoskonalenie szczepionek antywirusowych przez zastosowanie bezpiecznych ludzkich komórek diploidalnych (WI-38), co w pełni rozwiazało problem $z$ ówczesnym zakażeniem odzwierzęcym. H. Koprowski wraz $z$ lekarzem i biologiem molekularnym Stanleyem Plotkinem (1932-) opracowali skuteczna szczepionkę przeciw różyczce na bazie ludzkich komórek. W latach 80. XX w. w równym stopniu dzięki ogromnemu talentowi i przedsiębiorczości Koprowskiego, Instytut Wistara zajmował drugie miejsce w USA, za Stanford University, pod względem sumy przychodów $z$ tytułu praw autorskich za sprzedaż szczepionek.

W 1958 r. Koprowski przeprowadził $Z$ sukcesem jako pierwszy na świecie maso- wa akcję szczepień przeciw polio (250 tysięcy dzieci i niemowlat) w Kongu Belgijskim (obecnie Zair). W kolejnym roku, $z$ inicjatywy Feliksa Przesmyckiego, ówczesnego dyrektora Państwowego Zakładu Higieny, Koprowski przekazał bezpłatnie Polsce 9 milionów dawek szczepionek przeciwko polio farmaceutycznej firmy Wyeth. W Polsce, od 1951 r., trwała epidemia polio. Rocznie na tę chorobę zapadało do 3 tys. dzieci. Dzięki 8-miesięcznej akcji szczepień (od października 1959 do maja 1960 roku) liczba zachorowań w Polsce zmniejszyła się z 1112 przypadków w 1959 r., do około 30 przypadków w 1963 r., zaś liczba zgonów ze 111 do 2. Polska, dzięki szczepionce udostępnionej przez $\mathrm{H}$. Koprowskiego, była jednym $z$ pierwszych krajów w Europie, w których choroba Heine-Medina przestała występować.

$\mathrm{Na}$ przełomie lat 60. i 70. XX w. w Wistarze nastapiła intensyfikacja techniki hybrydyzacji komórek, służącej do wyizolowania przeciwciał. H. Koprowski, wspólnie Z włoskim lekarzem i genetykiem Carlo M. Croce, jako pierwsi na świecie opracowali hybrydomy wytwarzajace przeciwciała monoklonalne przeciwko antygenom wirusowym i rakowym. Hybrydomy otrzymywano z połaczenia komórki limfatycznej (limfocyty B) z komórka warunkujaca hybrydom nieśmiertelność (komórka szpiczakowa). Prace badawcze nad hybrydami przyczyniły się do zaawansowania badań wirusologicznych i onkologicznych oraz do powstania nowej dyscypliny nauki, tj. immunodiagnostyki. Nastała przełomowa era przeciwciał monoklonalnych, $z$ naciskiem na immunoterapie stanów nowotworowych u człowieka. Z inicjatywy $H$. Koprowskiego założono najlepiej prosperujaca w USA firmę biotechnologiczna Centocor, oparta na przeciwciałach monoklonalnych używanych do diagnozowania czynników patogenetycznych nowotworów i chorób zakaźnych. Firma Centocor stała się trzecia w Stanach Zjednoczonych firma biotechnologiczna pod względem dochodów.

W 1991 r. Koprowskiego zmuszono do opuszczenia Instytutu Wistara. Do usunięcia Pana Profesora $z$ Instytutu Wistara użyto argument podeszłego wieku (75 lat) oraz domniemanego deficytu finansowego (w rzeczywistości odpowiedzialna za sprawy finansowe była rada nadzorcza). Po nierównej batalii, prof. Koprowski, w 1992 r. rozpoczą prace w Uniwersytecie Thomasa Jeffersona w Filadelfii, w stanie Pensylwania; USA. Mimo sędziwego wieku, do śmierci pełnił funkcję profesora Instytutu Biotechnologii i Zaawansowanej Medycyny Molekularnej (Ryc. 1) oraz dyrektora Centrum Neurowirusologii i Laboratoriów Fundacji Biotechnologii. W nowej placówce naukowej głównym programem 


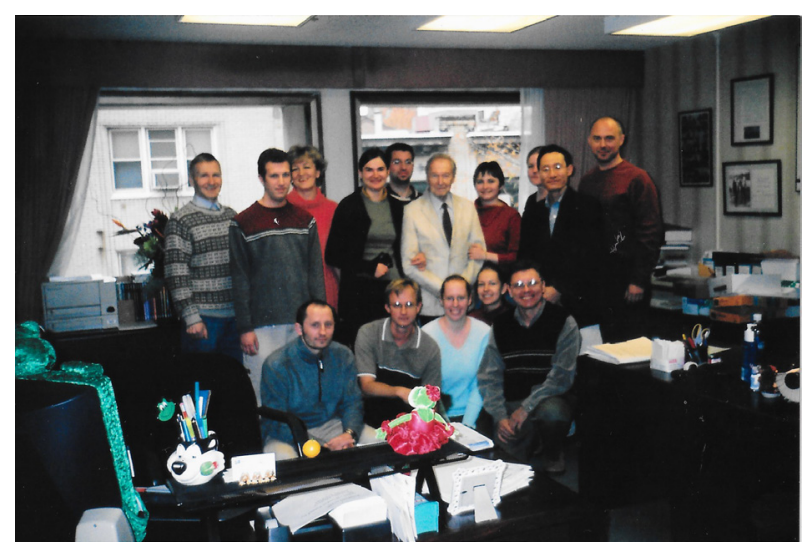

Ryc. 1. Prof. H. Koprowski $z$ zespołem naukowców Instytutu Biotechnologii i Zaawansowanej Medycyny Molekularnej w swoim gabinecie. 5.12.2005, TJU, Filadelfia, USA

badawczym Koprowskiego stały się szczepionki roślinne. Prowadzone były badania nad wprowadzaniem genów mikroorganizmów chorobotwórczych (wirusów, bakterii) do roślin (pomidory, tytoń, szpinak, aloes, kartofle), jako biogeneratorów ich rozwoju. Szczepionki roślinne miały być tańsza i wygodniejsza wersja szczepionek tradycyjnych. Przy użyciu tej technologii opracowano m.in. roślinna szczepionkę przeciwko wirusowi wścieklizny, wirusowi zapalenia wątroby typu B, antygenom raka jelita grubego. Pan Profesor prowadził intensywna współpracę $Z$ Instytutem Chemii Bioorganicznej PAN, Instytutem Włókien Naturalnych i Roślin Zielarskich w Poznaniu (Ryc. 2). i z Instytutem Biochemii i Biofizyki w Warszawie.

Do zespołu Pana Profesora dołaczyłam w sierpniu w 2005 r. Był troskliwym zwierzchnikiem, bardzo bezpośrednim w kontakcie,

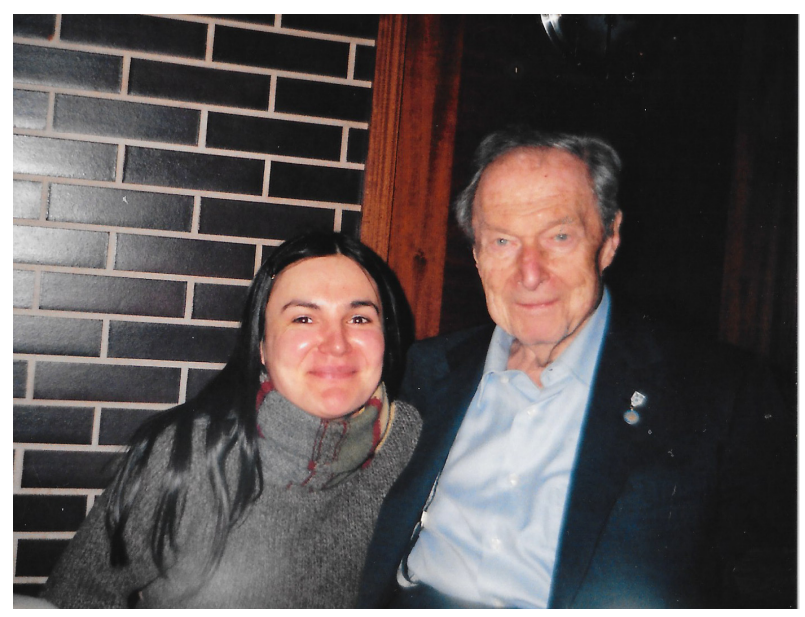

Ryc. 2. Z wizyta naukowa w Poznaniu. Profesor H. Koprowski $z$ autorka biogramu. 15 marzec 2009. Poznań.

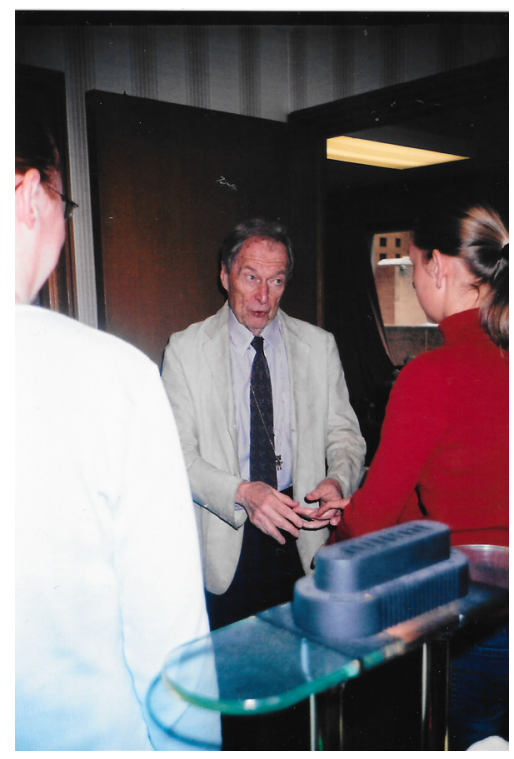

Ryc. 3. "Zawsze $z$ troska i bezcenna rada". 89. urodziny Pana Profesora. 5.12.2005. TJU, Filadelfia, USA.

o ogromnej intuicji i przenikliwym wzroku. Pomimo mocno dojrzałego wieku nie tracił rozpędu w niestrudzonej pracy badawczej. Miał wyjątkową umiejętność tworzenia pasjonującej, przyjaznej, kreatywnej atmosfery w laboratorium. Dbał o skuteczna i zdrowa interakcję w pracy zespołowej bez barier. Był wymagajacy, ale bardzo pomocny w sprawach zawodowych i również osobistych. Zapamiętałam Pana Profesora jako ciepłego, bezinteresownego, życzliwego człowieka, o bardzo osobliwym poczuciu humoru (Ryc. 3, 4). Miał bezszelestny chód. Raz po raz zza ramion osób pracujacych w laboratorium pojawiała się, ku ich wielkiemu zaskoczeniu (mojemu również), sylwetka uśmiechniętego Pana Profesora. Sam uważał siebie za dowcipnisia, kawalarza. Był znakomitym multi-

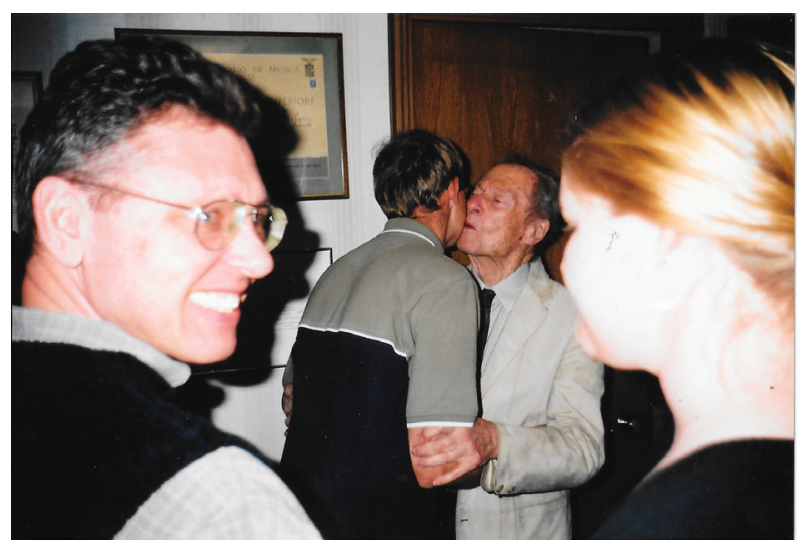

Ryc. 4. "Z kordialnym uściskiem". 89. urodziny Pana Profesora. 5.12.2005. TJU, Filadelfia, USA. 


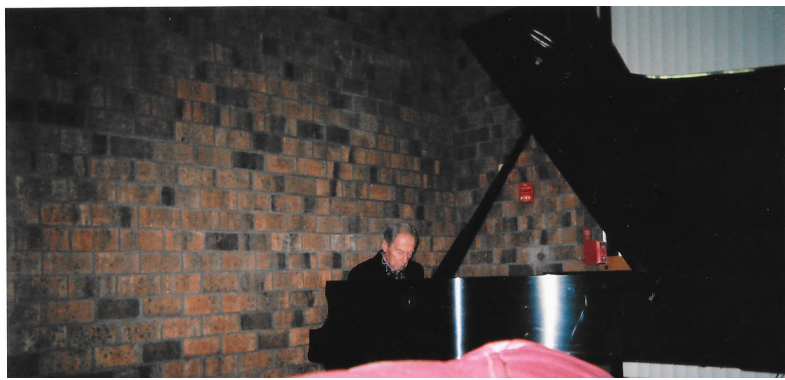

Ryc. 5. Kultowy bożonarodzeniowy recital fortepianowy Pana Profesora. Grudzień 2005, TJU, Filadelfia, USA.

języcznym wykładowca i gawędziarzem. Miał zwyczaj organizować raz w tygodniu zebrania (ang. lab meeting), gdzie analizowaliśmy bieżące sprawy naukowe. W ten sposób byliśmy zorientowani $\mathrm{w}$ badaniach, każdy mógł się ustosunkować i wyrazić bez obaw swoje uwagi. Nowości zawarte $\mathrm{w}$ prasie naukowej były dla Profesora niemal archiwalne. Uważał, że tylko bezpośrednie kontakty $\mathrm{z}$ drugim naukowcem moga być źródłem najświeższych informacji. W tym celu wciąż kontynuował liczne podróże naukowe po świecie. Był wrażliwy na uroki natury, szczególnie miał słabość do psów. W okresie światecznym miałam okazję uczestniczyć $\mathrm{w}$ tradycyjnym spotkaniu bożonarodzeniowym, na którym nie zabrakło kultowego recitalu fortepianowego (Ryc. 5, 6). Do dziś przechowuję podarunek świąteczny, płytę kompaktowa pt. Songs in the sky, autorstwa Pana Profesora, Andrew Blecknera i ...przyrody. Jest to swoisty kolaż muzyki instrumentalnej i śpiewu ptaków z Polski, Ameryki Północnej i Południowej.

Za życia Koprowskiego, nie zabrakło prób zakwestionowania renomy wielkiego uczonego. Niewatpliwie najgłośniejsza sprawa dotyczyła oskarżenia Koprowskiego o wybuch epidemii AIDS w Afryce, a w konsekwencji, na resztę globu. W 1992 r. w wysokonakładowym periodyku amerykańskim „Rolling Stone" ukazał sie artykul Toma Curtisa The Origin of AIDS. Spekulacja dotyczyła hipotezy wybuchu epidemii AIDS w Afryce wywołanej przez masowe szczepienia przeprowadzone przez Koprowskiego w stacji weterynaryjnej w Kongo Belgijskim. Hipoteza ta oparta była na opinii uczonych $z$ Kalifornii. Według nich, Koprowski do osłabiania wirusa polio wykorzystywał komórki pobierane $z$ nerek szympansów, które były nosicielami wirusa SIV (ang. Simian Immunodeficiency Virus), będącego zmutowanym odzwierzęcym prototypem (odpowiednikiem) wirusa HIV (ang. Human Immunodeficiency Virus). W rzeczywistości szczepionkę używaną do szczepień hodowano w nerkach małp pochodzacych $\mathrm{z}$

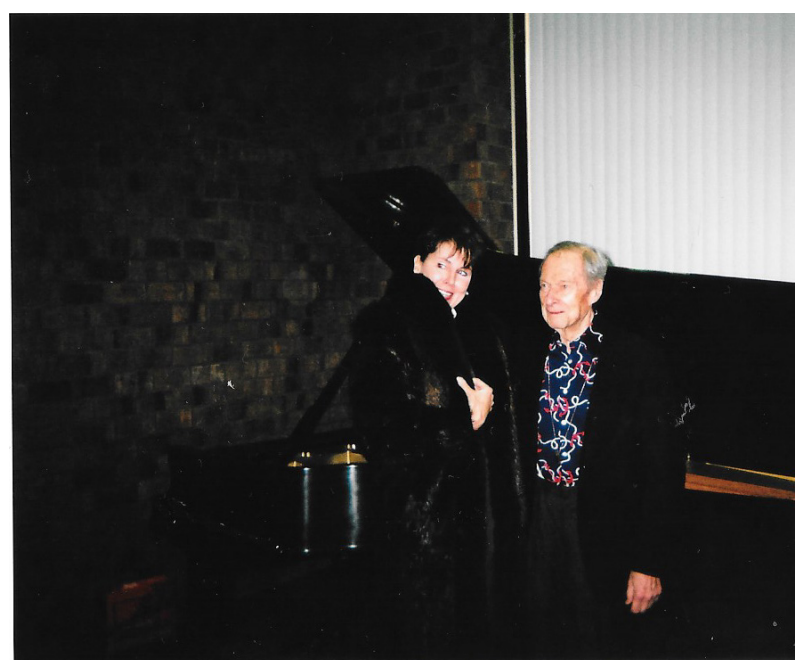

Ryc. 6. Prof. H. Koprowski $z$ długoletnią "wistarowska" asystentka Sue Jones. Spotkanie bożononarodzeniowe. Grudzień 2005, TJU, Filadelfia, USA.

Azji, tj. rezusów (Macaca mulatta), u których syndrom AIDS nie występuje. Sprawa zwiazku AIDS ze szczepionka Koprowskiego została ponownie poruszona 7 lat później przez brytyjskiego dziennikarza E. Hoppera w ksiażce The River: A Journey to the Source of HIV and AIDS. Dopiero kilka badań niezależnych ekspertów ostatecznie zaprzeczyło obecności wirusa SIV i DNA szympansów w szczepionce Koprowskiego. Były jedynie fragmenty tkanek rezusów, które nie choruja. Zarzuty zostały odparte. Wyniki opublikowano na łamach „Science”.

Niezależnie od intensywności pracy naukowo-badawczej, Koprowskiego zawsze w równym stopniu interesowały sprawy ludzkie, rodzinne. Pasjonowało go samo życie, któremu zawsze nadawał efektywna oprawę. Niezaprzeczalnie był artysta życia, spragnionym wszelkich jego przejawów. Żył według maksymy „Wygrać każdy dzień”. Jego pasją była muzyka, literatura i sztuka, podróże i przede wszystkim ludzie. Był koneserem malarstwa, głównie włoskiego oraz holenderskiego XVI i XVII wieku. Muzyka pochłaniała Koprowskiego całkowicie, była Jego skutecznym antidotum na wszelkie bolączki, stwarzała jedyny w swoim rodzaju stan równowagi, dystansowała Go od świata. $Z$ muzyki czerpał siłę i pogodę ducha.

Nie przywiazywał zbytniej wagi do swoich imponujących, licznych osiagnnięć na polu naukowym. H. Koprowski wiele razy publicznie powtarzał, że tytuły, zaszczyty, zasługi nie sprawiaja mu przyjemności: „Ci, którzy mnie znaja osobiście $i$ dobrze, co nie zawsze idzie $w$ parze, wiedza, że radość czerpie $z$ innych źródel, na przykład $z$ muzyki, 
na przykład z przyjaźni." To ludzie byli jego największą pasją, inspiracja. Był otwarty, przychylny w stosunku do ludzi najróżniejszego pochodzenia społecznego. $\mathrm{Na}$ pytanie, Co jest najważniejsze w życiu? Odpowiadał: robić coś dla innych. Być po prostu dobrym człowiekiem. I takiego Pana Profesora Koprowskiego zachowałam w pamięci...

\section{POSTSCRIPTUM}

Profesor Hilary Koprowski miał ogromny sentyment do willi swoich Rodziców w Celestynowie koło Otwocka, w którym spędził młodość i do której tak często wracał w myślach i wspomnieniach. Willa przetrwała wiele zawirowań historycznych (zawieruchę II wojny, czasy stalinowskie, komunizm) i była jedynym ostałym obiektem Jego dzieciństwa i młodości. To bardzo przejmujacy fakt, że nie przetrwała w wolnej Polsce. W 2004 r. rozebrano ja. Według koncepcji Profesora w dawnej posiadłości Ojca miała mieścić się fundacja Koprowskich, centrum dla naukowców $z$ biblioteka komputerową. Profesorowi Koprowskiemu udało się jedynie z Fundacją. Założona w 1989 r. Fundacja im. Koprowskich wspiera rozwój nauki w Polsce oraz polsko-amerykańska współpracę naukowa. Zawsze losy polskich naukowców nie były Mu obojętne. W trudnych okresach powojennej Polski wspierał polskich badaczy poprzez zakup deficytowych odczynników chemicznych, po dostęp do unikatowych wydawnictw naukowych. Umożliwiał polskim badaczom i naukowcom odbywanie praktyk i staży w kierowanych przez siebie instytucjach. Pomoc merytoryczna Pana Profesora dla polskich uczelni i placówek naukowych była $\mathrm{i}$ jest nie do przecenienia. Wyrazem wielkiego uznania dla wybitnych dokonań wzmacniajacych również polska naukę, popularyzacji idei humanizmu i podmiotowości w kontaktach międzyludzkich było uhonorowanie Profesora H. Koprowskiego zaszczytnym akademickim tytułem doktora honoris causa przez Uniwersytet Medyczny w Lublinie (1996 r.), Uniwersytet Medyczny w Poznaniu (1998 r.), Uniwersytet Medyczny w Warszawie (2000 r.) oraz Uniwersytet Przyrodniczy SGGW w Warszawie (2008 r.).

Wciąz jednak pozostaje pytanie otwarte: czy jest szansa na odtworzenie posiadłości w Celestynowie, miejsca od którego właściwie wszystko się zaczęło...dla trwałości pamięci o jednym $z$ najwibitniejszych polskich uczonych, ale i o Człowieku wielkiej klasy.

\section{POLECANA LITERATURA}

CROCE C. M., 2013. Hilary Koprowski (19162013): Vaccine pioneer, art lover, and scientific leader. Proc. Natil. Acad. Sci. USA 110, 8757.

KOPROWSKA I., 1998. O moim życiu i medycynie. Wspomnienia. Wydawnictwo Poznańskie. Poznań.

KOPROWSKI H., 1996. Wygrać każdy dzień. Diana, Warszawa.

KOPROWSKI H., UNIŃSKI H., 1939. Ammonia content of canine blood after oral administration of ammonium salts and ammonia. Bioch. J. 33, 747-753.

OSHINSKY D. M., 2015. Polio; Historia pokonania choroby Heinego-Medina. Prószyński Media, Warszawa.

PlotKIN S. A., 2013. In Memoriam. Hilary Koprowski; 1916-2013. J. Virol. 87, 8270-8271.

VAUGHAN R., 1999. Takty i fakty; Życie Hilarego Koprowskiego. Wydawnictwo Poznańskie. Poznań.

ZAGÓRSKI S., 2004. Gen ciekawości. Prószyński i S-ka SA, Warszawa. 